\title{
Genotypic identification of E.coli strains isolated from broilers.
}

\author{
Elsayed M.E. ${ }^{\text {; }}$ Esawy A. M. ${ }^{2}$; Rashed A. M.. ${ }^{2 *}$ \\ 1. Faculty of Veterinary Medicine, Suez Canal University. \\ 2, 2*. Animal Health Research Institute - Mansoura, Dakahlia.
}

\begin{abstract}
In this study bacteriological examination of 1200 samples were collected from 200 birds (60 recently dead, 80 diseased and 60 apparent healthy broilers). The results revealed that $E$. coli isolates were recovered from 842 samples with overall prevalence 70.16 . Incidence of positive E.coli from fresh heart blood samples was $75 \%$, liver $83 \%$, kidney $64 \%$, spleen $57 \%$, small intestine $74.5 \%$ and from bone marrow $67.5 \%$. Serological identification of randomly selected $E$. coli (20) isolates clarified that, one E. coli isolate was serotype $\mathrm{O}_{111}$, one was $\mathrm{O} 44$, one was $\mathrm{O} 55$, two were serotyped O142, two were serotyped O128, two were serotyped O158, three were serotyped O157, four were serotyped O29 and four were serotyped O115. PCR assay was carried out on six serovars $\left(\mathrm{O}_{142}\right.$, $\mathrm{O}_{29}, \mathrm{O}_{115}, \mathrm{O}_{158}, \mathrm{O}_{128}$ and $\left.\mathrm{O}_{157}\right)$ to detect the presence of $p h o A$, iss and iutA gene. All serovars have the three genes except $\left(O_{29}\right)$ does not possess iss gene.
\end{abstract}

\section{Introduction}

E. coli is a Gram-negative, nonspore-forming rod, which belongs to the family Enterobacteriaceae. The cell wall of Gram-negative bacteria typically consists of three layers, the cytoplasmic membrane and the outer membrane, separated by a peptidoglycan layer. The outer cell membrane contains phospholipids, membrane proteins and lipopolysaccharide (LPS). LPS comprises lipid-A, lipopolysaccharide core and repeated polysaccharide units called $\mathrm{O}$-antigens. Lipid-A is the lipophilic inner part of LPS. The toxic effects of LPS known as endotoxin. Here, the terms LPS and endotoxin are used synonymously (Hogan and Smith, 2003).

Colibacillosis refers to any localized or systemic infection caused entirely or partly by $E$. coli including colisepticaemia, coligranuloma, chronic respiratory disease (CRD), peritonitis, swollenhead syndrome, Artheritis, synovitis, panophthalmitis, perihepatitis and pericarditis (Gross, 1991).

Many species of E. coli are intestinal pathogens or commensals in the intestine of man and animals, birds, few are saprophytes in soil and water. some species are also transmitted between man and animals (WHO, 2000). 
Escherichiacoli is a commensal bacterium of chickens' intestine. However, some strains, extraintestinal avian pathogenic $E$. coli (APEC), are able to trigger invasive infections outside the intestine, namely colibacillosis (Barnes and Gross, 1997; Zhao et al, 2005). In avian strains of $E$. coli as with other bacterial pathogens, virulence is multifactorial and is associated with adherence factors (F1 and P-pili, and curli), the aerobactin ironsequestering system, serum resistance, capsule production, and temperature haemagglutination (tsh) (DhoMoulin et al, 1999).

The virulence associated genes such as fimC, astA, papC, tsh, fyuA, irp2, iucD, iss, hlyE, eaeA, vat, colV and stx $2 F$ play important roles individually or in combination in adhesion, ferric transport system, hemolyzation and toxin production of avian pathogenic E.coli (Yaguchi et al, 2007)

Multiplex PCR was used to identify traits that predict avian pathogenic Escherichia coli (APEC) virulence. five genes carried by plasmids were identified as being the most significantly associated with highly pathogenic APEC strains: iutA, $h l y F$, iss, iroN, and ompT (Johnson et al, 2008)

This study was planned to identify biochemically and serologically to determine $\mathrm{O}-$ antigen in the prevalent $E$. coli in broilers farms in Dakahlia Governorate, Egypt. Also, for detection of virulence genes of
E. coli using Polymerase Chain Reaction.

\section{Material and methods}

Samples collection according to Waltman et al (1998).

The samples were collected from 200 broiler chickens (60 recently dead, 80 diseased and 60 apparently healthy chicken). And these samples include liver, spleen , kidney, fresh heart blood, bone marrow and intestine. All samples were put in sterile plastic bags in ice box and transported directly to Mansoura laboratory (Animal Health Research Institute).

\section{Isolation of the $E$. coli isolates.}

The tested sample was initially inoculated into a non-inhibitory liquid medium to favour the repair and growth of stressed $E$. coli. The internal organs included liver, spleen , kidney, fresh heart blood, bone marrow and intestine were collected and pre-enriched in buffered peptone water as a $1: 10$ dilution and incubated at $37^{\circ} \mathrm{C} \pm 11^{\circ} \mathrm{C}$ for $18 \mathrm{~h}$.

Pre-enrichment culture was streaked onto non selective and selective agars for the isolation of E. coli 10 $\mu l$ loop-full from the inoculated and incubated pre enrichment culture were streaked on the surface of Nutrient agar, MacConkey agar, Xylose Lysine Deoxycholate agar (XLD agar) and Eosin methylene blue agar (EMB) and incubated at $37.0 \pm 1^{\circ} \mathrm{C}$ for $24 \mathrm{~h}$.

Identification of $E$. coli isolates: Microscopic examination 
Suspected purified colonies were prepared, fixed and stained with Gram's according to Murray et al (2003). Then examined microscopically.

Biochemical

Identification according to Murray et al (2003): Purified isolates were examined by different biochemical reactions either by oxidase, urea hydrolysis, $\mathrm{H}_{2} \mathrm{~S}$ production on TSI, lysine decarboxylation, indole, methyl red test, Voges-Proskauer, citrate utilization, motility test and Analytical profile index 20 E (API $20 \mathrm{E})$

Serological identification:

The preliminarily identified isolates biochemically as E. coli were subjected to serological identification according to Koneman et al (1999) for determination of $(\mathrm{O})$ antigen using slide agglutination test.
Antibacterial sensitivity testing:

The disk diffusion technique was applied according to Cruickshank et al (1975). Results were recorded and compared with the standard levels to know whether $E$. coli isolates were sensitive, intermediate, or resistant. The interpretation of inhibition zones of test culture was according to NCCLS (2002)

Detection of virulence genes in $E$. coli isolates using PCR:

1. Extraction of DNA according to QIAamp DNA mini kit instructions

2. Preparation of PCR Master Mix according to Emerald Amp GT PCR mastermix (Takara).

3. Cycling conditions of the primers during cPCR.

4. DNA Molecular weight marker.

Agarose gel electrophoreses

(Sambrook et al, 1989).

Table (1): Cycling conditions of the different primers during CPCR.

\begin{tabular}{|c|c|c|c|c|c|c|}
\hline Gene & $\begin{array}{c}\text { Primary } \\
\text { denaturation }\end{array}$ & $\begin{array}{c}\text { Secondary } \\
\text { denaturation }\end{array}$ & Annealing & Extension & $\begin{array}{l}\text { No. of } \\
\text { cycles }\end{array}$ & $\begin{array}{c}\begin{array}{c}\text { Final } \\
\text { extension }\end{array} \\
\end{array}$ \\
\hline phoA & $\begin{array}{c}94^{\circ} \mathrm{C} \\
5 \mathrm{~min} .\end{array}$ & $\begin{array}{c}94^{\circ} \mathrm{C} \\
45 \mathrm{sec} .\end{array}$ & $\begin{array}{c}58^{\circ} \mathrm{C} \\
40 \mathrm{sec} .\end{array}$ & $\begin{array}{c}72^{\circ} \mathrm{C} \\
45 \mathrm{sec} .\end{array}$ & 35 & $\begin{array}{c}72^{\circ} \mathrm{C} \\
10 \mathrm{~min} .\end{array}$ \\
\hline iss & $\begin{array}{c}94^{\circ} \mathrm{C} \\
5 \mathrm{~min} .\end{array}$ & $\begin{array}{c}94^{\circ} \mathrm{C} \\
30 \mathrm{sec} .\end{array}$ & $\begin{array}{c}54^{\circ} \mathrm{C} \\
30 \mathrm{sec} .\end{array}$ & $\begin{array}{c}72^{\circ} \mathrm{C} \\
30 \mathrm{sec} .\end{array}$ & 35 & $\begin{array}{c}72^{\circ} \mathrm{C} \\
10 \mathrm{~min} .\end{array}$ \\
\hline iutA & $\begin{array}{c}94^{\circ} \mathrm{C} \\
5 \mathrm{~min} .\end{array}$ & $\begin{array}{c}94^{\circ} \mathrm{C} \\
30 \mathrm{sec} .\end{array}$ & $\begin{array}{c}63^{\circ} \mathrm{C} \\
30 \mathrm{sec} .\end{array}$ & $\begin{array}{c}72^{\circ} \mathrm{C} \\
30 \mathrm{sec} .\end{array}$ & 35 & $\begin{array}{c}72^{\circ} \mathrm{C} \\
10 \mathrm{~min}\end{array}$ \\
\hline
\end{tabular}

\section{RESULTS}

The results illustrated in Table (2) demonstrated the Incidence of $E$. coli in examined broilers.

Results of positive cases showed high incidence of suspected E. coli isolates from dead chickens $92 \%$ (56 / 60), followed by diseased chickens $85 \%(86 / 80)$ and from apparently healthy chickens $70 \%$ (42 / 60) as shown in Table (2). The recovery rate of $E$. coli from 
internal organs is clarified in Table (3).

As shown in Table (3), the highest incidence of $E$. coli was recovered from liver $83 \%$ (166 / 200), followed by fresh heart blood $75 \%$ (150 / 200), small intestine $74.5 \%$ (149 / 200), bone marrow $67.5 \%$ (135 / 200), kidney $64 \%$ (128 / 200) and the lowest incidence was recovered from spleen $57 \%$ (114/ 200).

The morphological characters of $E$. coli clarified that E. coli isolates were G-ve rods appeared as pink colonies when cultured on MacConkey media, yellow on XLD and green metallic colonies on EMB medium.

Biochemically, all E. coli suspected isolates were lactose fermenting colonies and positive indole, methyl red, and Catalase. Meanwhile all isolates were negative oxidase, urea hydrolysis, citrate utilization, Voges-Proskauer and not produced $\mathrm{H}_{2} \mathrm{~S}$.

Results of serotyping of 20 E.coli isolates as shown in Table (4); revealed the high incidence of serotypes $\mathrm{O}_{29}$ and $\mathrm{O}_{115} \quad 4$ serotypes (20\%), followed by $\mathrm{O}_{157} \quad 3$ serotypes (15\%), then $\mathrm{O}_{142}, \mathrm{O}_{128}$ and $\mathrm{O}_{158} 2$ serotypes $(10 \%)$ and 1 serotype from $\mathrm{O}_{111}, \mathrm{O}_{44}$ and $\mathrm{O}_{55}$.

\section{Results of antibiotic sensitivity:}

From Table (5); the most encountered antimicrobial agents were Ampicillin, Oxytetracycline, Doxycycline, Neomycin and Gentamycin in percentages 65,55 ,
55,55 and $50 \%$ respectively while the lowest resistance percentages were to Erythromycin and Ciprofloxacin in percentages 25 and $20 \%$ respectively.

Result of detection of phoA, iss and iutA genes of isolated $E$. coli by using multiplex PCR were presented in Table (6) and photo (1, 2 and 3 ).

From Table (6), it was clear that the six tested E.coli servoars contain the 3 virulence genes ( $p h o A$, iss and iutA) except $\mathbf{O}_{29}$ which not had iss gene.

Photo (1,2 and 3): Agarose gel electrophoresis of phoA, iss and iutA genes from randomly selected E. coli ( 6 isolates ) L, $100 \mathrm{bp}$ lambda marker; and lane 2 represented the negative amplification of iss gene from $E$. coli isolates recovered from different sources. Positive amplification were presented as follow lane 1 phoA gene (720bp), iss gene (266bp) and iutA gene (300bp) isolated from Liver; lane 2 phoA gene and iutA gene isolated from Liver; lane 3 phoA gene, iss gene and iutA gene isolated from Bone marrow; lane 4 phoA gene, iss gene and iutA gene isolated from Liver; lane 5 phoA gene, iss gene and iutA gene isolated from Liver; lane 6 phoA gene, iss gene and iutA gene isolated from Kidney. 
Table (2) Incidence of E. coli in examined birds:

\begin{tabular}{|l|l|l|l|}
\hline \multirow{2}{*}{ case } & \multirow{2}{*}{ No. of birds } & \multicolumn{2}{|l|}{ Positive cases } \\
\cline { 3 - 4 } & & No. & $\%$ \\
\hline Apparently healthy chickens & 60 & 42 & $70 \%$ \\
\hline Diseased chickens & 80 & 68 & $85 \%$ \\
\hline Freshly dead chickens & 60 & 56 & $92 \%$ \\
\hline Total & 200 & 166 & $83 \%$ \\
\hline
\end{tabular}

Table (3) Recovery rate of E. coli isolates from examined organs of broilers.

\begin{tabular}{|c|c|c|c|c|}
\hline Organs & $\begin{array}{c}\text { Apparently } \\
\text { healthy chickens } \\
(\mathrm{n}=60)\end{array}$ & $\begin{array}{c}\text { Diseased } \\
\text { chickens } \\
(\mathrm{n}=80)\end{array}$ & $\begin{array}{c}\text { Dead } \\
\text { chickens } \\
(\mathrm{n}=60)\end{array}$ & Total \\
$(\mathrm{n}=200)$ \\
\hline $\begin{array}{c}\text { Fresh heart } \\
\text { blood }\end{array}$ & 35 & 62 & 53 & $150(75 \%)$ \\
\hline Liver & 42 & 68 & 56 & $166(83 \%)$ \\
\hline Kidney & 25 & 57 & 46 & $128(64 \%)$ \\
\hline $\begin{array}{c}\text { Small } \\
\text { intestine }\end{array}$ & 33 & 63 & 53 & $149(74.5 \%)$ \\
\hline Spleen & 17 & 48 & 49 & $114(57 \%)$ \\
\hline Bone marrow & 25 & 60 & 50 & $135(67.5 \%)$ \\
\hline
\end{tabular}

Table (4): Incidence and frequency distribution of E. coli serovars isolated from examined chickens.

\begin{tabular}{|c|c|c|c|c|}
\hline $\begin{array}{l}\text { E. coli } \\
\text { isolates }\end{array}$ & $\begin{array}{l}\text { No. of serotyped } \\
\text { isolates }\end{array}$ & $\begin{array}{c}\text { E. coli } \\
\text { serovars }\end{array}$ & No. & $\%$ \\
\hline \multirow{9}{*}{166} & \multirow{9}{*}{20} & O29 & 4 & $20 \%$ \\
\hline & & O158 & 2 & $10 \%$ \\
\hline & & O128 & 2 & $10 \%$ \\
\hline & & O142 & 2 & $10 \%$ \\
\hline & & O115 & 4 & $20 \%$ \\
\hline & & O157 & 3 & $15 \%$ \\
\hline & & O55 & 1 & $5 \%$ \\
\hline & & O44 & 1 & $5 \%$ \\
\hline & & $\mathrm{O}_{111}$ & 1 & $5 \%$ \\
\hline
\end{tabular}


Table (5): Antibiotic susceptibility of 20 E. coli serovars recovered from chickens for 10 Antimicrobial agents.

\begin{tabular}{|c|c|c|c|c|c|c|c|c|}
\hline \multirow{2}{*}{ Antimicrobial agent } & Conc. & \multirow{2}{*}{ Symbol } & \multicolumn{2}{|c|}{ Susceptible } & \multicolumn{3}{|c|}{ Intermediate } & \multicolumn{2}{c|}{ Resistant } \\
\cline { 4 - 9 } & & & NO. & $\%$ & NO. & $\%$ & NO. & $\%$ \\
\hline Ampicillin & 10 & AMP & 2 & 10 & 5 & 25 & 13 & 65 \\
\hline Gentamycin & 10 & $\mathrm{CN}$ & 5 & 25 & 5 & 25 & 10 & 50 \\
\hline Neomycin & 30 & $\mathrm{~N}$ & 2 & 10 & 7 & 35 & 11 & 55 \\
\hline Doxycycline & 30 & $\mathrm{DO}$ & 8 & 40 & 1 & 5 & 11 & 55 \\
\hline Oxytetracycline & 30 & $\mathrm{OT}$ & 7 & 35 & 2 & 10 & 11 & 55 \\
\hline Erythromycin & 15 & $\mathrm{E}$ & 6 & 30 & 9 & 45 & 5 & 25 \\
\hline Colistin & 10 & $\mathrm{CT}$ & 10 & 50 & 4 & 20 & 6 & 30 \\
\hline Streptomycin & 10 & $\mathrm{~S}$ & 7 & 35 & 4 & 20 & 9 & 45 \\
\hline Ciprofloxacin & 5 & $\mathrm{CIP}$ & 3 & 15 & 13 & 65 & 4 & 20 \\
\hline Florfenicol & 30 & Ffc & 11 & 55 & 3 & 15 & 6 & 30 \\
\hline
\end{tabular}

Table (6): Detection of virulence genes in recovery 6 E. coli isolates by using multiplex polymerase chain reaction ( $M P C R)$ :-

\begin{tabular}{|c|c|c|c|c|}
\hline No. & serotype & phoA & iss & iutA \\
\hline 1 & $\mathrm{O}_{142}$ & + & + & + \\
\hline 2 & $\mathrm{O}_{29}$ & + & - & + \\
\hline 3 & $\mathrm{O}_{115}$ & + & + & + \\
\hline 4 & $\mathrm{O}_{158}$ & + & + & + \\
\hline 5 & $\mathrm{O}_{128}$ & + & + & + \\
\hline 6 & $\mathrm{O}_{157}$ & + & + & + \\
\hline
\end{tabular}

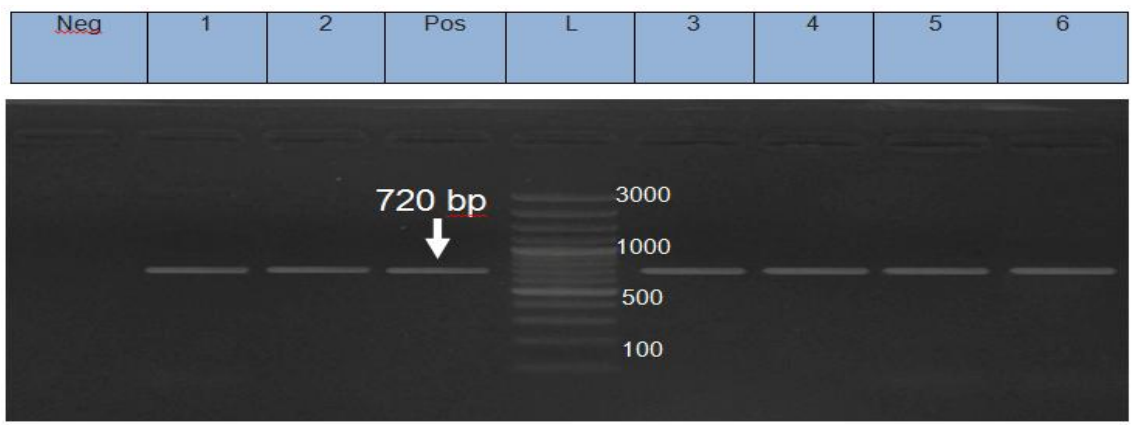

photo (1) Detection of $p h o A$ gene of E. coli at 720bp. lane 1 phoA gene (720bp) isolated from Liver; lane 2 isolated from Liver; lane 3 isolated from Bone marrow; lane 4 isolated from Liver; lane 5 isolated from Liver; lane 6 isolated from Kidney. 


\begin{tabular}{|l|l|l|l|l|l|l|l|l|}
\hline Neg & 1 & 2 & Pos & $\mathrm{L}$ & 3 & 4 & 5 & 6 \\
\hline
\end{tabular}

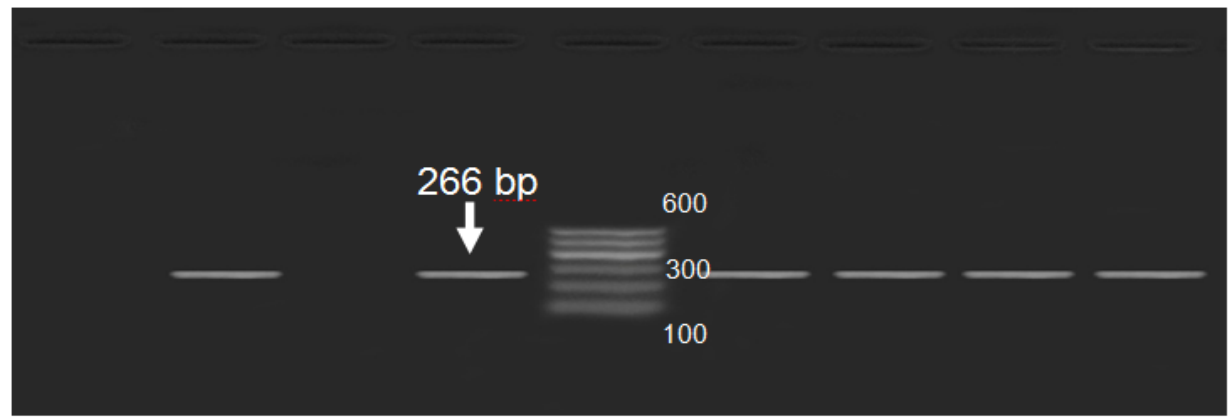

photo ( 2) Detection of iss gene of E. coli at 266bp. lane 1 iss gene (266bp) isolated from Liver; lane 2 was negative; lane 3 isolated from Bone marrow; lane 4 isolated from Liver; lane 5 isolated from Liver; lane 6 isolated from Kidney.

\begin{tabular}{|l|l|l|l|l|l|l|l|l|}
\hline Neg & 1 & 2 & Pos & $L$ & 3 & 4 & 5 & 6 \\
\hline
\end{tabular}

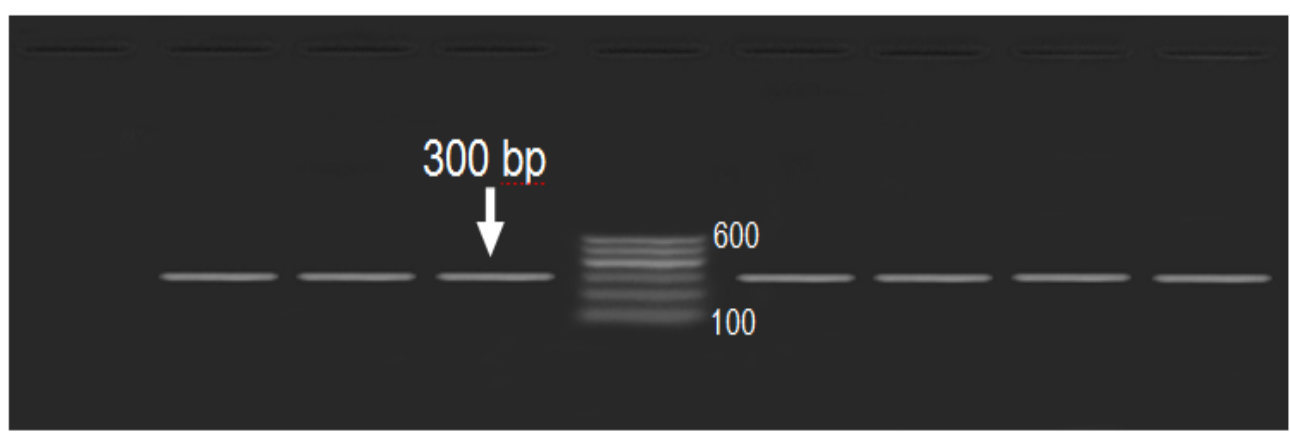

photo (3) Detection of $i u t A$ gene of $E$. coli at 300bp. lane 1 iutA gene (300bp) isolated from Liver; lane 2 isolated from Liver; lane 3 isolated from Bone marrow; lane 4 isolated from Liver; lane 5 isolated from Liver; lane 6 isolated from Kidney.

\section{DISCUSSION}

E. coli is considered as a member of the normal microflora of the poultry intestine, but certain strains such as those designated as avian pathogenic E. coli (APEC); spread into various internal organs and cause colibacillosis characterized by systematic fatal disease. (Someya et al, 2007)

Bacteriological study was conducted using randomly organ samples from recently dead, disease and healthy broilers including liver, fresh heart blood, kidney, spleen, small intestine and bone marrow from ten 
broiler farms located in Dakahlia governorate.

In general, investigation of 1200 organ samples collected from recently dead, disease and healthy broilers revealed that $E$. coli isolates was recovered from 842 samples with overall prevalence $(70.16 \%)$. Nearly similar results were recorded by Abd El Latif (2004) who isolated E.coli at a percentage of $(78.7 \%)$, Abd El-Salam (2004) who isolated 110 E.coli from broiler chickens at a percentage of (61\%), Sharada et al (2009) who recovered $E$. coli from $65(76.47 \%)$ samples out of the total 85 samples and Nashwa et al (2010) who isolated E.coli at a percentage of (75\%). Meanwhile Rahman et al (2004) who isolated E.coli at a percentage of $(40.82 \%)$, Akond et al (2009) who isolated E.coli at a percentage of (58\%) and Momtaz et al (2012) reported a lower prevalence for $E$. coli in a percentage ranged from (15.8 58\%). while $\mathbf{A b d} \mathbf{E l} \mathbf{A z i z}$ et al (2007) reported a higher prevalence for $E$. coli in a percentage $90 \%$. Concerning fresh heart blood samples, 150 out of 200 samples of examined fresh heart blood were $E$. coli positive with an incidence of (75\%). Nearly similar results were recorded by Saha et al (2003) who isolated 96 E.coli from of 165 samples (85\%). Meanwhile Abhilasha and Gupta (2001) reported a lower prevalence for $E$. coli in a percentage ranged from $(9.5-40.5 \%)$. Concerning liver samples, 166 out of 200 samples of examined liver were E. coli positive with an incidence of $(83 \%)$. While lower prevalence was detected by Abhilasha and Gupta (2001) who isolated E.coli from the liver at a percentage of (13.97\%), and Saha et al (2003) who isolated E.coli from the liver at a percentage of $(54.28 \%)$. Also, 128 out of 200 examined Kidney samples were $E$. coli positive with an incidence of 64\%. However, Sepehri and Zadeh (2006) recorded higher occurrence of $E$. coli from tested poultry kidney samples (96\%). Concerning small intestine samples, 149 out of 200 samples of examined small intestine were $E$. coli positive with an incidence of (74.5\%). Nearly similar results were recorded by Saha et al (2003) who isolated E.coli from the small intestine at a percentage of $(81.81 \%)$; Meanwhile Alireza et al (2007) reported a lower prevalence for $E$. coli in a percentage $37.5 \%$. Moreover, 114 out of 200 samples of examined spleen were $E$. coli positive with an incidence of $(57 \%)$. Nearly similar results were recorded by YunShifeng et al (1997) who recorded the percentage of the isolated $E$. coli was $48.44 \%$. while Saha et al (2003) reported a lower percentage $39.13 \%$ Finally, bone marrow samples, 135 out of 200 samples of examined bone marrow were $E$. coli positive with an incidence of (67.5\%). Sepehri and Zadeh (2006) recorded higher occurrence of $E$. coli from tested poultry bone marrow samples (96\%), while (48.44\%) lower 
prevalence was reported by YunShifeng et al (1997).

This study revealed that the $E$. coli isolates were isolated from 842 $(70.16 \%)$ out of 1200 broiler samples originated from different sources including; Fresh heart blood 150 out of 200(75\%), Liver 166 out of $200(83 \%)$, Kidney 128 out of 200(64\%), Small intestine 149 out of $200(74.5 \%)$, Spleen114 out of $200(57 \%)$ and bone marrow 135 out of $200(67.5 \%)$.

From the above mentioned results, it is obvious that $E$.coli isolates were recovered from poultry farms with higher prevalence from liver samples, followed by Fresh heart blood, Small intestine, Kidney, bone marrow and the lowest prevalence were from spleen. Furthermore, we can conclude that $E$. coli isolates were isolated from different organs at a percentage varied from $(57 \%)$ to $(83 \%)$. while the results $(39.13 \%)$ to $(81.81 \%)$ recorded by Saha et al ( 2003)

Typing of isolated bacteria, including E. coli could be achieved by Phenotypic and/or genotypic protocols. The phenotypic characteristic method used for identification of $E$. coli includes the morphological and biochemical tests. Most of these techniques are not sufficiently sensitive to distinguish between different strains and they are affected by physiological factors. (Fantasia $\boldsymbol{e t}$ al, 1990). Therefore, serological protocol was established to differentiate $E$. coli isolates.
Regarding the morphological characters used for identification of E. coli, depend on that E. coli isolates are Gram-negative rods appeared as pink colonies when cultured on MacConkey media, green metallic colonies on EMB medium. Nearly similar results were noted by McClure (2000) and Hogan and Smith (2003).

On the other aspect, results of biochemical tests by using traditional methods revealed that $90 \%$ of suspected isolates were biochemical identical to typical $E$. coli features and by using the API20E system for Identification of suspected isolated E. coli strains revealed that $100 \%$ of suspected isolates were biochemical identical to typical E. coli features. These results are similar to those recorded by (Timothy et al, 1985), who used the API 20E system for identification of isolated G-ve bacteria and observed that the API20E system identified about $98,9 \%$ of the isolated strains.

In the current study, 20 E.coli isolates recovered from broilers were serologically examined with available agglutinating sera according to Koneman et al (1999). The results clarified that, $1 E$. coli isolate was serotype $\mathbf{O}_{111}, 1$ was 044, 1 was 055, 2 were serotyped 0142, 2 were serotyped 0128, 2 were serotyped $\mathbf{0 1 5 8 , ~} 3$ were serotyped 0157, 4 were serotyped $\mathbf{O 2 9}$ and 4 were serotyped $\mathbf{0 1 1 5}$. These finding were similar to the results that was recorded from the 
chickens as the following; Taha et el (2002) and Ammar et al (2011) isolated $\mathrm{O}_{157}$ and $\mathrm{O}_{55}$, Sharaf (2000) isolated $\mathrm{O}_{115}$ and $\mathrm{O}_{29}$, Nashwa et al (2010) isolated $\mathrm{O}_{142}$, Fatma et al (2008) isolated $\mathrm{O}_{157}$ and $\mathrm{O}_{111}$, Perez-Guzzi et al (2000) isolated $\mathrm{O}_{44}$, Kumar et al (1996) isolated $\mathrm{O}_{128}$ and Ibrahim et al (1997) isolated $\mathrm{O}_{55}, \mathrm{O}_{111}$ and $\mathrm{O}_{158}$.

From the mentioned data, it was clear that the most prevalent $E$. coli serotype isolates recovered from examined broiler chickens samples were $\mathbf{O 1 1 5}$ and $\mathbf{O 2 9}$; followed by O157; then O158, 0128 and O142; and finally the lowest prevalent serotype were $\mathbf{0 5 5}, \mathbf{O 4 4}$ and $\mathbf{O}_{111}$. These results go in hand with those reported by Kumar et al., (2003) who recorded 0115 is one of the most predominant serogroups from many serotypes recovered from chickens $\quad\left(\mathbf{O}_{20}, \mathbf{O}_{54}, \mathbf{O}_{61}, \mathbf{O}_{73}, \mathbf{O}_{78}\right.$, $\mathbf{O}_{88}, \mathbf{O}_{89}, \mathbf{O}_{111}, \mathbf{O}_{115}, \mathbf{O}_{119}, \mathbf{O}_{132}$ and $\mathbf{O}_{153}$.

Antibiotic resistance is increasing among many bacterial species and is rapidly becoming a major world health problem Glynn et al (1998) and Roberts (1998). Antimicrobials are valuable tools to treat clinical disease and to maintain healthy and productive animals; however the treatment of whole herds and flocks with antimicrobials for disease prevention and growth promotion has become a controversial practice Witte (1998); Van Den Bogaard and Stobherinsh (1999).

Antimicrobial therapy is one of the primary control measures for reducing morbidity and mortality due to APEC associated avian coiibacillosis (Dho-Moulin and Fairbrother, 1999; White et al, 2000; Giraud et al, 2001 and Altekruse et al, 2002). Results of antibiotic sensitivity of serotyped $E$. coli recovered from broiler chickens showed that the majority of $E$. coli isolates possess resistance to ampicillin $(65 \%)$. followed by Oxytetracycline, Neomycin and Doxycycline $(55 \%)$. These results are nearly similar with Saha et al (2003) and El-Sayed and ElHanafy (2005) who reported that the highest resistance was to ampicillin and tetracyclines. These results also were confirmed by Zahraei Salehi and Farashi Bonab (2006) who proved that the highest rate of resistance was against Oxytetracycline (95\%), Doxycycline (88\%), Neomycin (81\%) and Ampicillin (47\%).

The isolates of E. coli showed $30 \%$ resistence to clostin and florfenicol and $20 \%$ to ciprofloxacin nearly similar results was recorded by Zahraei Salehi and Farashi Bonab (2006) who found that the resistance to clostin and Florfenicol were $(6 \%)$ and $(27 \%)$ respectively and was recorded by Miles et al (2006) who found that the resistance to ciprofloxacin was $11.8 \%$. And Bywater et al (2004) proved that the resistance was higher in case of old compounds than the newer compounds.

Finally one could conclude that the use of antibiotics is strongly 
associated with the prevalence of antimicrobial resistance in E.coli isolates in food-producing animals (Kang et al, 2005).

The present study was directed mainly to recognize some virulence genes, such as (phoA, iss and iutA genes) commonly found in E. coli isolated from various broiler farm samples by using one of the recent developments molecular biological techniques (multiplex PCR).Virulence genes of $E$. coli isolates recovered from broiler farms samples are shown in table (5) and photo 1 (A, B and C).

The choice of these genes due to iss and iutA were the most significantly associated with highly pathogenic APEC strains as mentioned by Johnson et al (2008). while phoA gene is a common gene specific to E.coli.

Concerning the examination of $E$. coli isolates for the detection of phoA gene showed that all isolates, table (5) yielded the expected size of $720 \mathrm{bp}$ PCR amplification products for the phoA gene and photo 1 (A). Nearly similar findings were recorded by Barry and Patrick (1980) who isolated a large number of PhoA gene. PhoA can be used specifically to detect bacterial genes that code for cell envelope proteins that recorded by Claude Gutierrez et al (1987).

Regarding the occurrence of iss gene in E. coli isolates. The results revealed that out of $6 E$. coli isolates recovered from broiler samples, 5 isolates were positive yielded the expected size of 266 bp PCR amplification by percent (83.3\%) 5 out of 6 . However, PCR results were negative for iss gene in other E. coli isolate Table (5) and photo 1 (B). Nearly similar findings were recorded by Elaine et al (2003) who reported that the iss gene was detected significantly more often amongst colibacillosis isolates. Also, Christa et al (2007) stated that plasmid-related gene was detected in the majority of avian pathogenic E.coli with iss present in (74.8 to 86.7\%)

Also, Catana et al (2008) recovered the gene iss which encodes a protein of the external membrane inducing resistance to the complement was present in 53 of the strains tested from 65 isolates by percent $81.5 \%$. Concerning the examination of $E$. coli isolates for the detection of iutA gene showed that all isolates, table (5) yielded the expected size of 300 bp PCR amplification products for the iutA gene and photo 1 (C). Nearly similar findings were recorded by Elaine et al (2003) who reported that the iutA gene was detected significantly in all colibacillosis isolates.

Finally one could conclude that the detection of phoA gene is necessary during detection E.coli as phoA gene is a common gene specific to E.coli.

\section{References}

Abd El Aziz, E.E.; Hassan, A.M. and Badr, J.M. (2007): In vitro efficacy of some antimicrobials on the E. coli and Mycoplasmal isolates 
from cases of chronic respiratory disease in broilers in Egypt. Zag. Vet. J., 35 (3): 40-49.

\section{Abd El-Latif, M.M. (2004): Escherichia coli associated with swollen head syndrome in broiler chickens. Assiut Vet. Med., J., 50(101): 212-234.}

Abd El-Salam, W. M. (2004): Further studies on Escherichia coli strains isolated from broiler chickens. Ph.D. Thesis (Bacteriology) Vet. Med. Cairo Univ., Egypt.

Abhilasha, S.P. and Gupta R.S. (2001): Pathogenicity and in vitro drug resistance of Escherichia coli isolated from colibacillosis cases in chicks of Tarai Region. Ind. J. of Comp. Micrbiol. Immunol. Infect. Dis., 22(2): 166-167.

Altekruse, S.F. ; Elvinger, F, .; Lee, K. y.; Tollefson, L. K.; Pierson E. w.; Eifert, j. and sriranganathan, N. (2002): Antimicrobial susceptibilities of $E$. coli strains from a turkey operation. J. Am. Vet. Med. Assoc.221:411416.

Akond, S. A, S.M.R. Hassan andMomena Shirin (2009): "Antibiotic Resistance of Escherichia Coli Isolated From Poultry and Poultry Environment of Bangladesh". Internet Journal of Food Safety, Vol.11,2009, p. 19-23

Alireza S, Seyed Z M, Mahmoud S, Mohammad C, AHA $S$ and Reza P (2007): "Detection and investigation of Escherichia coffin contents of duodenum, jejunum, ileum and cecum of broilers at different ages by PCR" AsPac J.
Mol. Biol. Biotechnol. 2007 Vol. 18 (3): 321-326.

Ammar A. M, Norhan KA, Yousreya HM and Abd ElAziz EE (2011): "Advanced studies on Diagnosis of Single M. gallisepticum infection and combined with E.coli in chickens". Zag. VetJ. (ISSN. 1110-1458).

Barnes, H.J., Gross, W.B., (1997). Colibacillosis. In: Calnek, B.W., Barnes, H.J., Beard, C.W., McDougald, L.R., Saif, Y.M. (Eds.), Diseases of Poultry. Iowa State University Press, Ames, IA, pp. 131-141.

Barry L. Wanner and Patrick Latterell (1980): Mutants affected in alkaline phosphatase expression : Evidence for multiple positive regulators of the phosphate regulon in E. coli. Genetics journal, vol. 96 no. 2 353-366

Bywater, R.; Deluyker, H.; Deroover, E.; Jong, A.de.; Marino, H.; McConville, M.; Rowan, T.; shryock, T.; Shuster, D.; Thomas, V.; Valle, M. and Walters, J.(2004): European survey of Antimicrobial susceptibility among zoonotic and commensal bacteria isolated from food producing animals. J. Antimicrob. Chemother. 54(4): 744754.

Catana, Nl.,Virgilia Popa, lonica Fodor, Maroiu G(2008): "Molecular screening regaring the presence of the Iss genes FIM and OPMA at the E.coli isolated from the broiler chickens". Buletin USAMV Veterinary 
Medicine, 65(2) /2008 pISSN 18435270; eISSN 1843-5378.

Christa, E.; Granwu, L.; Ilendrik, W.; Sabine, K.; Katja, A.; Esther-Maria, A.; Claudia, L.; Ines, D.; Susaimc, G.; Timo, H.; Vte, B.; Hartmut, S.; Hans-C, P. and Lother, H. (2007): Avian pathogenic, uropathogenic and newborn meningitis-causing E.coli: How closely related are they?. Journal of applied Microbiology, 297: 163-176.

Claude Gutierrez, James Barondess, Colin Manoil and Jon Beckwith (1987): The use of transposon TnphoA to detect genes for cell envelope proteins subject to a common regulatory stimulus analysis of osmotically regulated genes in Escherichia coli. Journal of Molecular Biology, Volume 195, Issue 2, Pages 289-297.

Cruickshank, R.; Duguiel, J.P.; Marmion, B.P. and Swain, R.H.A. (1975): Medical microbiology. 12th ed. Vol. II Churchill Living stone, Edenburg, London and New York. Des; 5: 895-913.

Dho-Moulin, M. and Fairbrother, J.M.(1999): Avian Pathogenic E. coli (APEC) Vet. Res. 30:299-316.

Elaine, R. D.; Benito, G. B.; Luis, C. J.; and Marilda, C. V.(2003): Virulence -associated genes in E.coli isolates from poultry with colibacillosis. Veterinary Microbiology. 94: 97103

El-Sayed, A. and El-Hanafy, M. M.(2005): Antimicrobial exposures as a risk factor for emergency of multidrug resistance and failure of antimicrobial therapy. J. Egypt. Vet. Med. Assoc. 65(5):15-25.

Fantasia, M,; Ricci, N.; Manupella, A.; Martinil, A.; Filetici, E.

and Lnrelli,T. (1990): Phage type and DNA plasmid of Salmonella typhimurium isolates in the area of Isernia, Italy. Epidemiol. Infect. 109(3):167-323.

Fatma M. Yousseff, Mona, A. Ahmed, and Dalia H. Mansour (2008): "Clinical, Pathological and Bacteriological Investigations on Air Sacculitis in Chickens in Ismailia Province (Egypt)". Journal of Agricultural and Veterinary Sciences, Qassim University, Vol. 1. No. 2, pp. 71-79

Giraud, E.; Leroy- Setrin, S.; Flaujae, G.; Cloeckaert, A.; DhoMoulin, M. and Chaslus- Dancla, E.(2001): Characterization of high-level fluroroquinolone resistance in E. coli O78:K80 isolated from turkeys. J. Antimicrob. Chemother. 47: 341343.

Glynn, M.K.; Bopp, C.; Dewitt, W.; Dabney ,P.; Mokhtar, M. and Angulo, F.J.(1998): Emergency of multidrug resistant Salmonella enterica serotype typhimurium infections in the USA. N. Engl. J. Med. 338: 13331337.

Gross,W.B. (1991): Collibacillosis in poultry : Diseases of poultry. $9^{\text {th }}$ Ed.Pp. 138 -144 Editors : Calenk, B. W. et al. lowa State Univ. Press, 
Ames lowa, USA.

Hogan J. and Smith K.L. (2003): Coliform mastitis. Vet. Res. 34: 507- 519.

Ibrahim, A.I.; El-Attar, A.A. and El-Shahidy, M. S. (1997): Studies on E.coli isolates from respiratory affected broilers and protection evaluation of different prepared bacterines. Assiut Vet. Med. J., 37(74): 152-162.

Johnson, T.J.; Wannemuehler, Y.; Doetkott, C.; Johnson, S.J.; Rosenberger, S.C. and Nolan, L.K. (2008): Identification of minimal predictors of avian pathogenic Escherichia coli virulence for use as a rapid diagnostic tool. J. Clin. Microbiol., 46 (12): 3987-3996.

Kang, H.Y.; Jeong, Y.S.; Oh, J.Y.; Tae, S.H.; Choi, C.H.; Moon, D.C.; Lee, W.K.; Lee, Y.c.; Seol, S.Y. and Cho, D.T.(2005): characterization of antimicrobial resistant and class I integrons found in E. coli isolates from humans and animals in Korea . J. Antimicrob. Chemother. 55: 639-644.

Koneman, E. W.; Allen, S.D.; Janda, W. M.; Schreckenberger, P. C. and Winn, W.C.(1999) : color atlas and textbook of diagnostic microbiology $4^{\text {th }}$ Ed. J. B. Lippincott company, Philadelphia, P.A.

Kumar, K.U.; Sudhakar, R. and Rao, P.P. (1996): A note on Escherichia coli infection in poultry. Poultry Adviser., 21(6):4951.

McClure, P. G. (2000): Microbiological hazard identification in the meat industry. HATCP in the meat industry. CRC PRESS wood head publishing limited, Cambridge. 2000:157-176. Miles, T.D.; McLaughlin, W. and Brown, P.D. (2006): Antimicrobial resistance of E.coli isolates from broiler chickens and humans. Vet. Res. 2:7.

Momtaz, andMoshkelaniS. (2012) :"Molecular detection of antimicrobial resistance genes in $E$. coli isolated from slaughtered commercial chickens in Iran" Veterinarni Medicina, 57,2012 (4): 193-197

Murray P.R., Baron E.J., Pfaller M.A., Jorgensen J.H., Yolken R.H. (2003): Manual of clinical Microbiology $8^{\text {th }}$ Ed., Vol. 1, ASM, PRESS. Washington, D.C.

Nashwa .A.Ezz El Deen, Mohamed Kh. F. and Nahla A. H (2010): "Characterization of surface proteins of E.coli isolated from different Egyptian sources". Inter. J of micro.1(3):147-161.

\section{NCCLS}

Committee for Clinical

Laboratory Standards), (2002):

Performance Standards for Antimicrobial Disk and Dilution Susceptibility Tests for BacteriaIsolated from Animals. Second Edition; Approved Standard. NCCLS document M31-A2. Wayne, PA 19087-1898, 2002.

Perez-Guzzi，J.I.; Folabella，A.; Miliwebsky, E.; Rivas, M.; Fernandez-Pascua, C.; Gomez, D.; Zamora, A.; Zotta, C. and 
Cordoba, -M. (2000): Isolation of Escherichia coli $\mathrm{O}_{157}: \mathrm{H}_{7}$ in combined-sewer outflows with fecal bacterial contamination in Mar del Plata. Revista-Argentina-deMicrobiologia., 32(3): 161-164.

Rahman, M. A.; Samad, M. A.; Rahman, M. B. and Kabir, S.M.L. (2004): Bacteriopathological studies on salmonellosis, colibacillosis and pasteurellosis in natural and experimental infections in chickens. Bangl. J. Vet. Med., 2(1): 1-8.

Roberts, M. C.(1998): Resistance mechanisms in bacteria of oral and upper respiratory origin. Int. J. Antimicrob. Agents4:255-267.

Saha, A.; Hui, A.K; Das, R.; Roy, J.P.; Ray, N. and Mahata,T.K (2003): Occurrence of Escherichia coli from broiler birds in West Bengal and their antibiogram. India. J. Anim. Hlth., 42(2): 136-141.

Sambrook, J.; Fritscgh, E.F.;and Mentiates (1989): Molecular coloning. A laboratory manual. Vol 1., Cold spring Harbor Laboratotry press, New York.

Sepehri, G. and Zadeh, A.-H. (2006): Prevalence of bacterial resistance to commonly used antimicrobials among Escherichia coli isolated from chickens in Kerman Province of Iran. J. Med. Sci. Pakistan., 6(1): 99-102 .

Sharada R., Ruban S.W. and Thiyageeswaran M. (2009): "Antibiotic Resistance Pattern Of
Escherichia coli Isolated From Poultry In Bangalore "The Internet Journal of Microbiology ISSN: 1937-8289.

Sharaf, E.M.F.A.A. (2000): Some studies on the virulence attribute of E.coli isolated from chickens in Assiut. M.V.Sc. Thesis (Poultry Diseases). Fac. Vet. Med., Assiut University.

Someya, A.; Otsuki, K. and Murase, T. (2007): Characterization of Escherichia coli strains obtained from layer chickens affected with colibacillosis in a commercial egg-producing farm. J. Vet. Med. Sci., 69 (10): 1009-1014.

Taha, M.; Ibrahim, R. S. and Asmaa, A.A.H. (2002): Studying the pathogenicity and RAPD- PCR analysis of different Escherichia coli serotypes isolated from broilers and layer chickens. Assiut Vet. Med. J., 46(92): 224-236.

Timothy, L.; Daniel, D.; Sue, B. and Narman, L. (1985): Comparison of the API Rapid 20 E four-hour system with the API $20 \mathrm{E}$ overnight system for identification of routine clinical isolates of the Family Enterobacteriaceae. J. of clinical Microbiol., 21(4):542-545.

Van Den Bogaard, A.E. and Stobberingh, E. E.(1999): Antibiotic usage in animals : impact on bacterial resistance and public health. Drugs 58: 589-607.

Waltman W.D., Gast R.K., Mallinson E.T. (1998): Salmonellosis in: A Laboratory Manual for the Isolation and 
Identification of Avian Pathogens, 4th Edition, American Association of Avian Pathologists, 2-13.

WHO( World Health Organization ) (2000) : Food safety and food borne illness. Fact. Sheet NO. 237.

White, D.G.; Piddock, L. J. V.; Maurer, J.J.; Zaho, S.; Ricci, V. and Thayer, S.G.(2000): Characterization fluroroquinolone resistance among veterinary isolates of avian E. coli. Antimicrob. Agents Chemother. 44(10):28972899.

Witte, W. (1998): Medical consequences of antibiotic use in agriculture. Sci. 279:996-997.

Yaguchi, K.; Ogitani, T.; Osawa, R.; Kawano, M.; Kokumai, N.; Kaneshige, T.; Noro, T.; Masubuchi, K. and Shimizu, Y. (2007): Virulence factors of avian pathogenic Escherichia coli strains isolated from chickens with colisepticemia in Japan. Avian Dis., 51 (3): 656-662.

Yun-Shifeng, S.; Lan, Z.R.; wang, W.W.; Zheng, M.Q.; Chai, B.; Yun, S.F.; Lan, Z.R.; Wang, W.W.; Zheng, M.Q. and Chai, B.X. (1997): Characterization of avian Escherichia coli in Jiangsu. Acta Agriculturae Shanghai., 13(4): 7-10.

Zahraei Salehi T. and Farashi Bonab S. (2006): Antibiotics Susceptibility Pattern of Escherichia coli Strains Isolated from Chickens with Colisepticemia in Tabriz Province, Iran International Journal of Poultry Science 5 (7): 677-684. Zhao, S.; Maurer, J.J.; Hubert S/; De Villena J.F.; McDermott P.P.; Meng J.; Ayers S.; English L. and White D.G. (2005): Antimicrobial susceptibility and molecular characterization of avian pathogenic Escherichia coli isolates. Vet. MicrobioL 107 (3-4): 215-224.

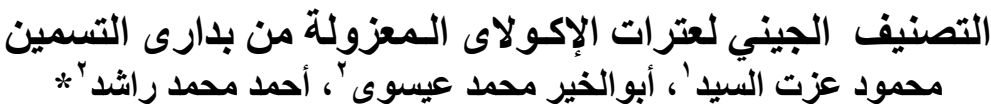

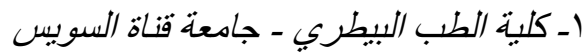

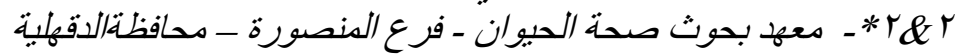

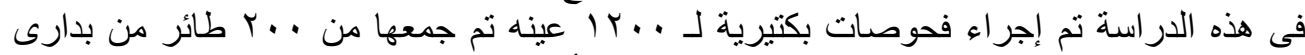

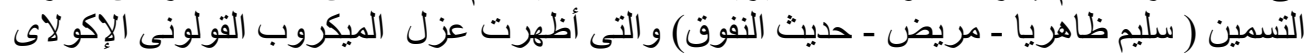

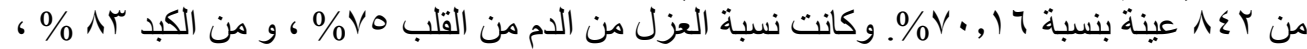

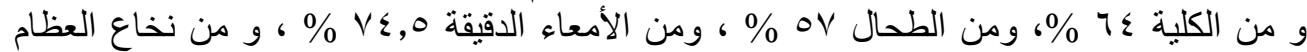

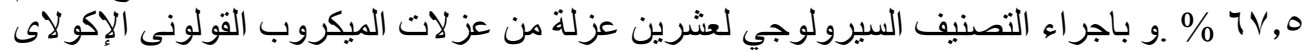

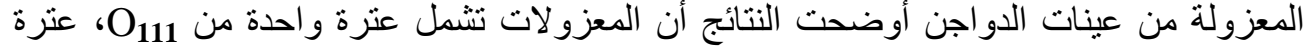

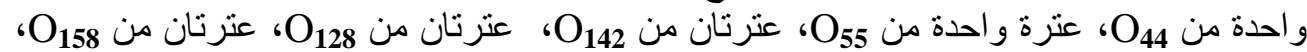

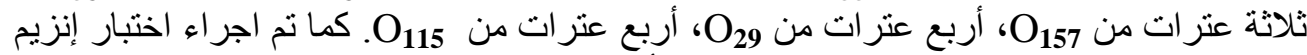
البلمرة المتسلسل التعددي لستة من المعزولات الأتية: $)$ تبين وجود الثلاث جينات ( phoA, iss and iutA) فى جميع العترات باستثناء جين ( iss) غير 